\title{
ISOLASI ASAM-9Z,12Z,15Z-OKTADEKATRIENOAT DARI BIJI SELASIH (Ocimum basilicum)
}

\author{
A. Ghanaim Fasya ${ }^{1,}$, Rurini Retnowati ${ }^{2}$, M. Farid Rahman ${ }^{2}$, Suleman Duengo ${ }^{3}$ dan Warsito ${ }^{2}$ \\ (1) Jurusan Kimia, Fakultas Sains dan Teknologi, UIN Maulana Malik Ibrahim Malang \\ (2) Jurusan Kimia, Fakultas MIPA, Universitas Brawijaya, Malang \\ (3) Jurus an Kimia, Universitas Negeri Gorontalo \\ Corresponding_author: agfasya.uinmalang@gmail.com / 081331087496
}

\begin{abstract}
The $\alpha$-linolenic acid $(9,12,15$-octadecatrieonic acid) is omega-3 fatty acid that more active than other fatty acids to inhibit cell membrane damages, formation and growth of brain functions, antiinflamatory and prevent several cronic deseases like lung desease and arthryt is. Some research explain that geometri of omega-3 fatty acids had effect on its bioactivity. This research purpose was to is olate $\alpha$-linolenic acid with geometry $Z, Z, Z$ (9Z,12Z,15Z-oktadekatrienoat).

O. basilicum seeds oil was isolated from $O$. basilicum seeds using Soxhlet extraction with n-hexane, then hidrolized by $12 \%$ solution of $\mathrm{KOH}$ in aquadest. The $\alpha$-linolenic acid was separated from other fatty acids by urea inclusion methods. The optimum condition of urea inclusion was determined in various temperature $(+5,+3,+1,+(-1),+(-3),+(-5)){ }^{0} \mathrm{C}$ and ratio of fatty acid : urea $1: 1 ; 1: 1,5 ; 1: 2 ; 1: 2,5 ; 1: 3 ; 1: 3,5 ; 1: 4$.

From this research, extraction of $O$. basilicum seeds oil with n-hexane as solvent resulted clear yellowbrown oil with refractive indeks 1,466 and density $0,855 \mathrm{~g} / \mathrm{mL}$. Gas Chromatography (GC) analysis of fatty acids hidrolyzed from $O$. basilicum oil showed peak at $t_{\mathrm{R}}=19,949$ minutes with relative percentage $70,72 \%$. Base on Mass Spectrum (MS), the fragmentation of this compound, with $t_{R}=19,949$ minutes, was identic with 9Z,12Z,15Z-oktadecatrienoic acid. Isolation of $\alpha$-linolenic acid from other fatty acids using urea inclusion at temperature $0-2{ }^{0} \mathrm{C}$ dan rasio fatty acid: urea 1:1,5 showed nonadduct fraction contains compound with $t_{R}=$ 19,980 minutes and relative percentage 88,51 \%. Base on Mass Spectrum (MS), the fragmentation of this compound, with $t_{R}=19,980$ minutes, was identic with $9 Z, 12 Z, 15 Z$-oktadecatrienoic acid.
\end{abstract}

Key words : conjugated double bond, methyl linolenate, O.basilicum seeds, toxicity

\begin{abstract}
ABSTRAK
Asam $\alpha$-linolenat (asam 9,12,15-oktadekatrienoat) merupakan asam lemak omega-3 yang diketahui mempunyai khasiat yang lebih baik dibanding asam-asam lemak yang lain dalam mencegah rusaknya membran sel, berperan dalam pembentukan dan pertumbuhan fungsi otak, mengurangi pembengkakan, serta membantu mencegah berbagai penyakit kronis seperti jantung dan arthritis. Beberapa penelitian menyebutkan geometri as am lemak omega-3 mempunyai efek terhadap bioaktivitasnya. Penelitian ini bertujuan untuk mengisolasi asam $\alpha$-linolenat dengan geometri Z,Z,Z (9Z,12Z,15Z-oktadekatrienoat).

Isolasi minyak dari biji selasih dilakukan dengan metode ekstraksi Soxhlet menggunakan pelarut $\mathrm{n}$ heksan. Minyak biji selasih selanjutnya dihidrolisis dengan larutan $\mathrm{KOH} 12 \%$ dalam aquades untuk mendapatkan asam-asam lemaknya. Pemisahan asam $\alpha$-linolenat dari asam-asam lemak yang lain dilakukan dengan metode inklusi urea. Kondisi optimum inklusi urea dilakukan dengan variasi temperatur $(+5,+3,+1,+$ $(-1),+(-3)$ dan $+(-5)){ }^{0} \mathrm{C}$ serta variasi rasio as am lemak:urea $1: 1 ; 1: 1,5 ; 1: 2 ; 1: 2,5 ; 1: 3 ; 1: 3,5 ; 1: 4$.

Dari hasil penelitian, diperoleh minyak biji selasih berwarna kuning kecoklatan dengan indeks bias 1,466 dan densitas $0,855 \mathrm{~g} / \mathrm{mL}$. Hasil analisis Kromatografi Gas (KG) terhadap asam lemak hasil hidrolisis minyak biji selasih menunjukkan puncak utama pada $t_{R}=19,949$ menit dengan persen relative $70,72 \%$. Berdasarkan Spektra Massa (SM), pola fragmentasi senyawa dengan $t_{R}=19,949$ menit tersebut mempunyai kemiripan dengan spektra massa asam 9Z,12Z,15Z-oktadekatrienoat. Hasil analis is KG terhadap hasil pemisahan asam-asam lemak minyak biji selasih dengan metode inklusi urea pada temperatur $0-2{ }^{0} \mathrm{C}$ dengan rasio asam lemak: urea 1:1,5 menunjukkan puncak utama pada $t_{R}=19,980$ menit dengan persen relatif $88,51 \%$. Berdasarkan Spektra Massa (SM), pola fragmentasi senyawa dengan $t_{R}=19,980$ menit tersebut mempunyai kemiripan dengan spektra massa as am 9Z,12Z,15Z-oktadekatrienoat.
\end{abstract}

Kata kunci : ikatan rangkap terkonjugasi, metil linolenat, biji O.basilicum, toksisitas 


\section{PENDAHULUAN}

Asam linolenat merupakan asam lemak esensial, yaitu asam lemak yang tidak dapat dibentuk dalam tubuh, sehingga harus dikonsumsi melalui makanan (Harrison, 2006). Asam linolenat merupakan asam lemak tak jenuh jamak (polyunsaturated fatty acid, PUFA) rantai lurus yang tersusun dari 18 atom karbon. Memiliki dua bentuk isomer, yaitu $\alpha$ linolenic acid (ALA) dan $\gamma$-linolenic acid (GLA), yang keduanya memiliki kerangka karbon mengandung ikatan rangkap yang belum terkonjugasi. Secara IUPAC nama struktur kimia dari ALA adalah asam 9,12,15-oktadekatrienoat, sedangkan GLA adalah asam 6,9,12-oktadekatrienoat.

Asam $\alpha$-linolenat (ALA), adalah asam lemak omega-3 yang dikenal memiliki khasiat lebih daripada asam-asam lemak lain, khususnya dalam mencegah rusaknya membran sel. Selain berguna untuk pertumbuhan normal, omega 3 juga mempunyai peranan yang kritis dalam pembentukan dan pertumbuhan fungsi otak. Penelitian yang lebih mendalam juga menemukan bahwa asam lemak omega 3 bisa mengurangi pembengkakan dan membantu mencegah beberapa penyakit kronis seperti penyakit jantung dan arthritis (Muhsin, 2007).

Asam $\alpha$-linolenat dapat diisolasi dari minyak yang kaya akan asam linolenat, seperti halnya minyak biji selasih (Ocimum basilicum). Minyak biji selasih memiliki kandungan asam lemak tidak jenuh yang cukup tinggi yaitu rata-rata $89 \%$. Kandungan asam lemak dalam minyak biji selasih yaitu: asam $\alpha$-linolenat $(43,8-64,8$ $\%)$, asam linoleat $(17,8-31,3 \%)$, dan asam oleat $(8,5-13,3 \%)$ serta beberapa asam lemak jenuh yaitu asam palmitat $(6,1$ - 11,0 \%) dan asam stearat $(2,0-4,0 \%)$ (Angers, et al., 1996).

Asam $\alpha$-linolenat pada minyak biji selasih dapat diisolasi dengan berbagai metode. Salah satunya menggunakan metode kristalisasi pada temperatur bertingkat, yaitu $\pm 3, \pm(-13)$, dan $\pm(-25)$
${ }^{0} \mathrm{C}$. Hasil penelitian menunjukkan bahwa pada temperatur $-25{ }^{0} \mathrm{C}$ diperoleh asam $\alpha$ linolenat dengan kemurnian 91,3957 \%, densitas $0,9 \mathrm{~g} / \mathrm{mL}$, indeks bias 1,47 serta rendemen 72,38 \% (Dewi, 2009). Metode lain yang digunakan untuk mengisolasi asam $\alpha$-linolenat adalah inklusi urea (urea inclusion). Inklusi urea merupakan metode isolasi yang dilakukan dengan penambahan urea yang mampu membentuk kisi-kisi kristal yang mempunyai ruang yang cukup besar untuk dimasuki suatu molekul yang akan dipisahkan. Pada inklusi urea asam lemak tertentu akan membentuk kompleks dengan urea sehingga pengendapan asam lemak akan terjadi pada temperatur yang lebih tinggi. Metode inklusi urea tidak memerlukan pendinginan pada temperatur yang ekstrim (Ohlan, et al., 2008).

Isolasi asam lemak menggunakan inklusi urea telah dilakukan pada pemurnian asam dokosaheksaenoat (DHA) dari mikroalga Crypthrcodinium cohnii. Hasil penelitian menunjukkan bahwa fraksi dengan proporsi DHA paling tinggi $(99,2 \%$ dari total asam lemak dengan hasil 6,2 \%) adalah pada temperatur $4{ }^{0} \mathrm{C}$ dan perbandingan urea:asam lemak 3,5:1 (Mendes, et al., 2006). Sedangkan Grandgirard (1987) telah melakukan inklusi urea pada asam lemak minyak biji rami (linseed oil) dengan perbandingan urea:asam lemak 2:1 pada temperatur $4{ }^{0} \mathrm{C}$ menghasilkan pemisahan antara asam $\alpha$ linolenat dan asam non linolenat. Asamasam lemak non linolenat terperangkap dalam kristal urea seperti asam palmitat $99,1 \%$, asam palmitoleat $62,5 \%$, asam heptadekanoat $100 \%$, asam heptadekaenoat $75 \%$, asam stearat $99,4 \%$, asam oleat 89,8 $\%$, asam linoleat $(18: 2 Z, E$ dan $E, Z) 83 \%$ dan $(18: 2 Z, Z) 34,9 \%$. Hanya sedikit asam $\alpha$-lonolenat $(18: 3 \quad Z, Z, Z)$ yang terperangkap, yakni sekitar $27,1 \%$ dan sisanya tetap berada dalam filtrat.

\section{METODE PENELITIAN}

Penelitian ini terdiri dari tiga tahap. Tahap pertama, Ekstraksi minyak dari biji 
selasih (Ocimum basilicum). Tahap kedua, hidrolisis minyak biji selasih untuk memperoleh asam-asam lemak minyak biji selasih. Tahap ketiga, isolasi asam $\alpha$ linolenat dengan geometri Z,Z,Z (9Z,12Z,15Z-oktadekatrienoat) dengan metode inklusi urea (urea inclusion).

\section{Ekstraksi Minyak Biji Selasih}

Sebanyak $200 \mathrm{~g}$ serbuk biji selasih ditimbang dan dimasukkan ke dalam kertas saring yang telah dibentuk tabung. Selanjutnya dimasukkan ke dalam ekstraktor Soxhlet dan diekstraksi dengan pelarut n-heksana sebanyak $800 \mathrm{~mL}$. Ektraksi dilakukan sebanyak 12 kali sirkulasi hingga pelarut yang merendam sampel terlihat jernih. Ekstrak yang berwarna kekuningan dipekatkan menggunakan rotary evaporator dengan pengurangan tekanan. Ekstrak pekat dipindahkan ke dalam botol dan dialiri gas $\mathrm{N}_{2}$, kemudian ditutup, dan disimpan pada temperatur dingin. Minyak yang berwarna kekuningan diukur berat jenis dan indeks biasnya.

\section{Hidrolisis Minyak Biji Selasih}

Sebanyak $50 \mathrm{~g}$ minyak biji selasih dimasukkan ke dalam labu alas bulat leher tiga yang dirangkai dengan penangas air dan kondensor. Selanjutnya ditambahkan $100 \mathrm{~mL}$ metanol dan larutan KOH 12 \% (12 $\mathrm{g}$ dilarutkan dalam $100 \mathrm{~mL}$ air). Campuran direfluks pada temperatur $60{ }^{0} \mathrm{C}$ sambil diaduk menggunakan stirer selama 90 menit (cairan tampak kuning jernih). Cairan hasil refluks dipindahkan ke dalam corong pisah dan ditambahkan $250 \mathrm{~mL}$ air dan $62,5 \mathrm{~mL}$ n-heksana. Kemudian larutan dikocok dengan kuat dan didiamkan hingga terbentuk dua lapisan, yaitu lapisan organik di bagian atas dan lapisan air di bagian bawah. Lapisan air dipisahkan dan ditambahkan asam sulfat $1 \mathrm{M}$ sampai $\mathrm{pH} 1$ ( $\mathrm{pH}$ diukur dengan indikator universal). Kemudian cairan dikocok dengan kuat dan didiamkan hingga terbentuk dua lapisan, yaitu lapisan organik di bagian atas dan lapisan air di bagian bawah. Lapisan atas yang mengandung asam-asam lemak bebas dipisahkan dari lapisan bawah dan dipekatkan dengan mengalirkan gas $\mathrm{N}_{2}$. Selanjutnya, asam-asam lemak bebas yang diperoleh dipisahkan dengan inklusi urea untuk memperoleh asam $\alpha$-linolenat yang terpisah dengan asam-asam lemak nonlino lenat.

\section{Isolasi Asam Linolenat dengan Inklusi Urea}

\section{Optimasi Inklusi Urea dengan Variasi Temperatur}

Sebanyak 2,5 g asam lemak biji selasih dicampurkan pada larutan urea dalam metanol hangat $(5 \mathrm{~g}$ urea/ $20 \mathrm{~mL}$ metanol). Setelah dialiri gas $\mathrm{N}_{2}$, didinginkan semalam pada variasi temperatur $+5{ }^{0} \mathrm{C},+3{ }^{0} \mathrm{C},+1{ }^{0} \mathrm{C},+(-1){ }^{0} \mathrm{C}$, $+(-3){ }^{0} \mathrm{C}$ dan $+(-5){ }^{0} \mathrm{C}$. Asam lemak yang terendapkan bersama urea dan asam lemak yang tidak terendapkan dipisahkan dengan penyaringan. Kristal (residu) dibilas dengan n-heksan dingin. Filtrat dituang ke dalam corong pisah, ditambah $35 \mathrm{~mL}$ aquades dan $0,5 \mathrm{~mL} \mathrm{HCl} 6 \mathrm{~N}$. Selanjutnya di ekstrak dengan n-heksan sebanyak 2 x $10 \mathrm{~mL}$. Fase organik dipisahkan dari fase air untuk selanjutnya dipekatkan dengan aliran gas $\mathrm{N}_{2}$. Asam linolenat yang diperoleh diesterifikasi untuk selanjutnya diidentifikasi dengan kromatografi gas (GC).

\section{Optimasi Inklusi Urea dengan Variasi Rasio Urea:Asam lemak}

Sebanyak 2,5 g asam lemak biji selasih dicampurkan pada larutan urea dalam metanol hangat [variasi berat urea $(2,5 ; 3,75 ; 5 ; 6,25 ; 7,7 ; 8,75 ; 10)$ g]. Setelah dialiri gas $\mathrm{N}_{2}$, didinginkan semalam pada temperatur optimum inklusi. Asam lemak yang terendapkan bersama urea dan asam lemak yang tidak terendapkan dipisahkan dengan penyaringan. Kristal (residu) dibilas dengan n-heksan dingin. Filtrat dituang ke dalam corong pisah, ditambah $35 \mathrm{~mL}$ aquades dan $0,5 \mathrm{~mL} \mathrm{HCl} 6 \mathrm{~N}$. Selanjutnya di ekstrak dengan n-heksan sebanyak 2 x 10 $\mathrm{mL}$. Fase organik dipisahkan dari fase air untuk selanjutnya dipekatkan dengan aliran 
gas $\mathrm{N}_{2}$. Asam linolenat yang diperoleh diesterifikasi untuk selanjutnya diidentifikasi dengan kromatografi gas (GC).

\section{Isolasi Asam Linolenat pada Kondisi Optimum Inklusi}

Isolasi asam $\alpha$-linolenat dengan inklusi urea dilakukan secara bertahap (tiga tahap) pada kondisi optimum yang diperoleh dari penelitian sebelumnya, yaitu pada temperatur $0-2{ }^{0} \mathrm{C}$ dan rasio asam lemak:urea 1:1,5.

Sebanyak $15 \mathrm{~g}$ asam lemak biji selasih dimasukkan ke dalam botol berisi larutan urea dalam metanol (22,5 $\mathrm{g}$ urea/ 90 $\mathrm{mL}$ metanol) dengan temperatur $\quad 40{ }^{0} \mathrm{C}$ dan diaduk sampai tercampur. Setelah dialiri gas $\mathrm{N}_{2}$, campuran didinginkan dan didiamkan semalam pada temperatur $0-2$ ${ }^{0} \mathrm{C}$. Asam lemak yang mengendap bersama urea dan asam lemak yang tidak mengendap dipisahkan dengan penyaringan menggunakan kertas saring Whatman no.1. Residu (endapan) dibilas dengan n-heksana dingin $\left(0-2{ }^{0} \mathrm{C}\right)$. Filtrat yang diperoleh dari hasil penyaringan dituang ke dalam corong pisah, ditambah 112,5 mL aquades dan 2,25 $\mathrm{mL} \mathrm{HCl} 6 \mathrm{~N}$. Setelah dikocok, campuran diekstrak dengan n-heksana sebanyak 2 x $20 \mathrm{~mL}$. Fase organik (lapisan atas) dipisahkan dari fase air (lapisan bawah) untuk selanjutnya dipekatkan menggunakan rotary evaporator dengan pengurangan tekanan. Ekstrak pekat dipindah ke dalam botol, dialiri gas $\mathrm{N}_{2}$, kemudian ditutup dan disimpan pada temperatur dingin. Cairan pekat yang diperoleh diinklusi dengan prosedur yang sama (inklusi tahap II dan III).

Cairan pekat yang diperoleh diesterifikasi untuk sebagian dianalisis dengan kromatografi gas-spektroskopi massa (KG-SM).

\section{HASIL DAN PEMBAHASAN}

\section{Hasil Isolasi Minyak Biji Selasih}

Minyak biji selasih merupakan trigliserida yang larut dalam pelarut nonpolar. Isolasi minyak biji selasih dilakukan dengan cara ekstraksi Soxhlet dengan pelarut n-heksana. Ekstraksi dengan ekstraktor Soxhlet merupakan cara ekstraksi minyak yang efisien karena pelarut dapat digunakan secara berulang-ulang, sehingga tidak membutuhkan pelarut dalam jumlah yang banyak. Pelarut n-heksana yang ditempatkan pada labu alas bulat akan menguap dan mengembun ke dalam tabung ekstraktor yang berisi sampel yang terbungkus kertas saring sehingga terjadi proses ekstraksi. Pelarut berinteraksi dengan sampel sampai volume tertentu, campuran pelarut dan minyak yang terekstrak di dalamnya akan turun ke labu alas bulat dan mengalami pemanasan kembali sehingga pelarut akan menguap dan mengembun lagi ke dalam tabung ekstraktor. Proses ekstraksi terjadi berkalikali sampai beberapa kali sirkulasi. Selama berlangsungnya ekstraksi, ekstrak yang turun ke labu alas bulat semakin jernih sedangkan ekstrak dalam labu alas bulat semakin pekat warnanya yang mengindikasikan minyak yang terekstrak semakin banyak. Dalam penelitian ini, proses ektraksi berlangsung secara maksimal pada sirkulasi ke-12 ditandai warna campuran yang sudah jernih dan diasumsikan semua minyak yang terkandung dalam sampel biji selasih sudah terekstrak semua.

Sebelum proses ekstraksi, sampel biji selasih dikeringkan dan diperkecil ukurannya terlebih dahulu. Hal ini dimaksudkan untuk memudahkan dan memaksimalkan proses ekstraksi. Apabila sampel masih basah, selain memperlambat proses ekstraksi, air dapat turun ke labu alas bulat sehingga akan mempengaruhi kemurnian minyak biji selasih yang diperoleh. Biji selasih dipanaskan dalam oven pada temperatur $110{ }^{0} \mathrm{C}$ untuk mengurangi/ menghilangkan kadar air di dalamnya. Pemanasan dilakukan selama kurang lebih 2 jam, didinginkan dalam desikator dan ditimbang. Perlakuan ini dilakukan sampai diperoleh berat konstan.

Ekstraksi minyak biji selasih dilakukan dengan memasukkan 200 g serbuk biji 
selasih ke dalam kertas saring yang telah dibentuk tabung, selanjutnya dimasukkan ke dalam ekstraktor Soxhlet dan diekstraksi dengan pelarut n-heksana sebanyak 800 $\mathrm{mL}$. Ekstraksi dilakukan sebanyak 12 kali sirkulasi. Setiap sirkulasi rata-rata terjadi selama 15 menit. Ekstrak yang diperoleh dipekatkan dengan rotary evaporator dengan pengurangan tekanan. Ekstrak pekat yang diperoleh dimasukkan ke dalam botol, dialiri gas $\mathrm{N}_{2}$ untuk selanjutnya ditutup dan dibungkus alumunium foil serta disimpan pada temperatur dingin. Hasil ekstraksi minyak biji selasih ditunjukkan pada Gambar 1.

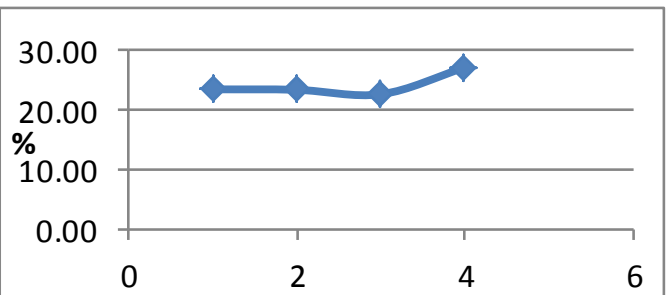

Gambar 1. Rendemen Ekstraksi Minyak Biji Selasih

$\begin{array}{rrrr}\text { Gambar } & 1 & \text { menunjukkan rendemen } \\ \text { hasil isolasi } & \text { minyak biji } & \text { selasih }\end{array}$ menggunakan ekstraktor Soxhlet dengan pelarut n-heksana. Hasil penelitian menunjukkan pada ekstraksi biji selasih diperoleh minyak dengan rendemen ratarata $24,16 \%$. Minyak biji selasih yang diperoleh dari hasil percobaan memiliki indeks bias rata-rata 1,4661 dan berat jenis 0,8553. Sedangkan menurut Angers, et al. (1996), minyak yang diperoleh dari biji selasih memiliki indeks bias sebesar 1,474 dengan rendemen $24 \%$. Berdasarkan nilai indeks bias, terlihat bahwa kualitas minyak biji selasih hasil isolasi mendekati kualitas minyak hasil isolasi yang dilakukan oleh Angers et al. (1996). Adanya sedikit perbedaan pada indeks bias minyak biji selasih dimungkinkan karena perbedaan daerah asal biji selasih yang digunakan, sehingga sedikit mempunyai perbedaan pada komposisi asam-asam lemak yang terkandung di dalamnya. Untuk mengetahui komposisi asam-asam lemak yang terkandung di dalamnya, minyak biji selasih dihidrolisis untuk mendapatkan asam-asam lemaknya.

\section{Hasil Hidrolisis Minyak Biji Selasih}

Minyak biji selasih yang merupakan trigliserida akan terhidrolisis menjadi asamasam lemak dan gliserol. Hidrolisis minyak biji selasih dilakukan dengan katalis basa $(\mathrm{KOH})$ dan pelarut metanol. Dalam hal ini $\mathrm{KOH}$ yang digunakan dibuat berlebih dengan perhitungan trigliserida yang bereaksi adalah gliseril trilinolenat. Reaksi hidrolisis minyak berkatalis basa berlangsung melalui mekanisme serangan nukleofilik yang terdiri dari dua tahap. Tahap pertama, yang berjalan lambat, yaitu adisi $\mathrm{OH}^{-}$pada gugus karbonil. Sedangkan tahap kedua yaitu eliminasi gugus OR' dan transfer proton yang berjalan cepat. Mekanisme reaksi hidrolisis pada trigliseril linolenat dapat dijelaskan pada Gambar 2.

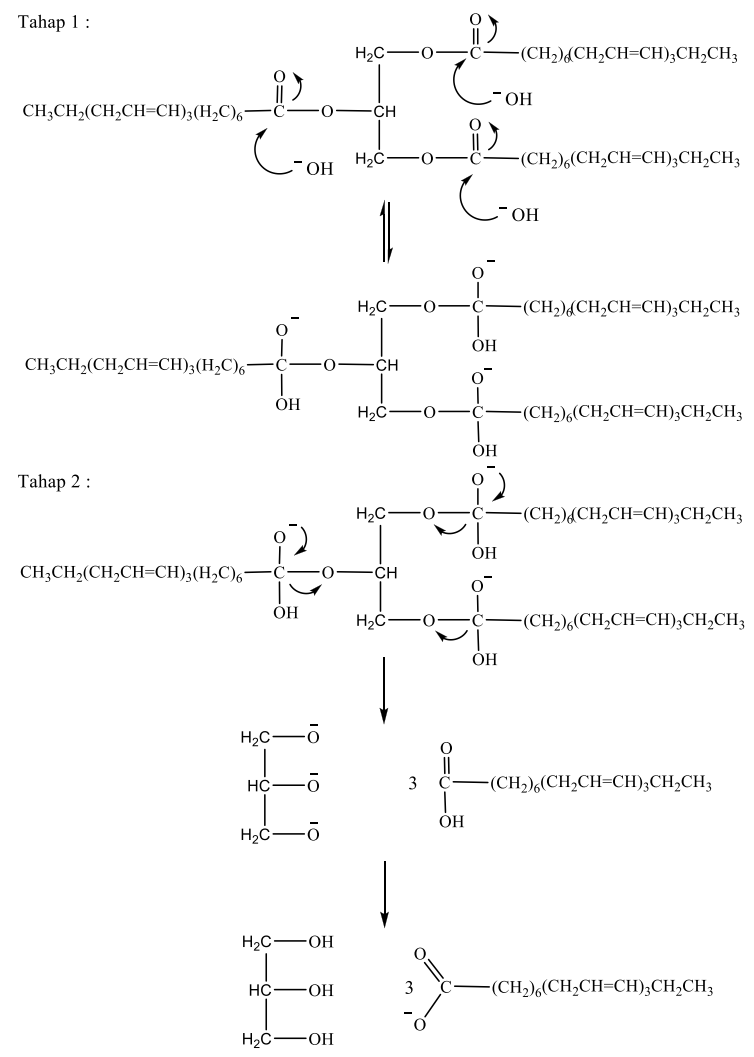

Gambar 2. Mekanisme Reaksi Hidrolisis Trigliseril Linolenat berkatalis Basa

Hasil hidrolisis berupa garam (sabun) kalium yang larut dalam air yang ditandai terbentuknya busa pada saat ekstraksi dengan corong pisah. Untuk 
memperoleh asam lemak dilakukan penambahan asam sulfat pada lapisan air hingga $\mathrm{pH} 1$ untuk memastikan semua garam berubah menjadi asam lemak. Asam lemak bebas diekstrak dengan menggunakan n-heksana. Fasa organik dipekatkan dengan mengalirkan gas $\mathrm{N}_{2}$ sehingga diperoleh asam-asam lemak bebas yang berwarna kuning jernih agak kecoklatan. Selanjutnya diukur berat jenis dan indeks biasnya. Hidrolisis minyak biji selasih menghasilkan campuran asam-asam lemak dengan rendemen sebanyak 77,90\%, recovery $81,81 \%$, indeks bias 1,4593 , dan berat jenis 0,8853 . Dengan kata lain, dari $100 \mathrm{~g}$ minyak diperoleh $77,90 \mathrm{~g}$ asam lemak yang merupakan $81,81 \%$ dari asam lemak teoritis dengan asumsi minyak biji selasih mengandung gliseril trilinolenat. Sebagian asam lemak diesterifikasi untuk selanjutnya dianalisis dengan kromatografi gas-Spektroskopi Massa (KG-SM). Gambar 3. dan Tabel 1 menunjukkan kromatogram KG metil ester asam lemak hasil hidrolisis.

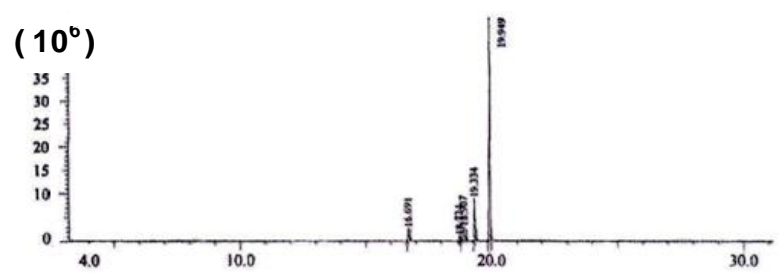

Gambar 3. Kromatogram KG Metil Ester Asam Lemak Hasil Hidrolisis

Tabel 1. Waktu Retensi dan Persen Area Puncak-Puncak Kromatogram KG Metil Ester Asam Lemak Biji Selasih

\begin{tabular}{|l|l|l|l|}
\hline Peak & $\begin{array}{c}\mathrm{t}_{\mathrm{R}} \\
(\text { menit})\end{array}$ & $\begin{array}{c}\text { Luas } \\
\text { Puncak }\end{array}$ & \multicolumn{1}{|c|}{ Senyawa } \\
\hline 1 & 16,691 & $4,98 \%$ & $\begin{array}{l}\text { asam palmitat (asam } \\
\text { heksadekanoat) }\end{array}$ \\
\hline 2 & 18,724 & $2,02 \%$ & $\begin{array}{l}\text { asam stearat (asam } \\
\text { oktadekanoat) }\end{array}$ \\
\hline 3 & 18,907 & $6,46 \%$ & $\begin{array}{l}\text { asam oleat (asam } \\
\text { oktadeka-11-enoat) }\end{array}$ \\
\hline 4 & 19,334 & $15,83 \%$ & $\begin{array}{l}\text { asam linoleat (asam } \\
9 E, 12 E \text { - } \\
\text { oktadekadienoat) }\end{array}$ \\
\hline 5 & 19,949 & $70,72 \%$ & $\begin{array}{l}\text { asam } \alpha \text {-linolenat (asam } \\
9 Z, 12 Z, 15 Z- \\
\text { oktadekatrienoat) }\end{array}$ \\
\hline
\end{tabular}

Tabel 1 menunjukkan bahwa minyak biji selasih terdiri dari beberapa asam lemak yang ditunjukkan adanya 5 puncak pada kromatogram KG. Puncak pertama dengan waktu retensi 16,691 memiliki luas area 4,98 \% diduga merupakan asam palmitat (asam heksadekanoat). Puncak kedua dengan waktu retensi 18,724 memiliki luas area $2,02 \%$ diduga merupakan asam stearat (asam oktadekanoat) karena memiliki spektra massa yang sesuai dengan spektra massa metil oktadekanoat dari WILLEY7.LIB dengan nomor entry 209846 dan tingkat kemiripan $87 \%$. Puncak ketiga dengan waktu retensi 18,907 memiliki luas area $6,46 \%$ diduga merupakan asam oleat (asam oktadeka-11enoat) karena memiliki spektra massa yang sesuai dengan spektra massa metil oktadeka-11-enoat dari WILLEY7.LIB dengan nomor entry 207875 dan tingkat kemiripan $91 \%$. Puncak keempat dengan waktu retensi 18,334 memiliki luas area $15,83 \%$ diduga merupakan asam linoleat (asam 9E,12E-oktadekadienoat) karena memiliki spektra massa yang sesuai dengan spektra massa metil 9E,12Eoktadekadienoat dari WILLEY7.LIB dengan nomor entry 205807 dan tingkat kemiripan $96 \%$.

Senyawa dengan puncak paling tinggi (puncak V) dengan waktu retensi 19,949 menit yang diperkirakan sebagai asam $\alpha$-linolenat memiliki persen area sebesar 70,72. Spektra massa komponen utama metil ester asam lemak hasil hidrolisis $\quad\left(t_{R}=19,949\right) \quad$ menghasilkan puncak ion fragmen pada $\mathrm{m} / \mathrm{z}: 39,41,55$, 67, 79, 93, 108, 121, 135, 149, 163, 173, 191, 203, 217, 236, 249, 261, 277, dan 292. Fragmen dengan m/z 292 merupakan ion molekul metil linolenat yang memiliki rumus $\mathrm{CH}_{3} \mathrm{CH}_{2}\left(\mathrm{CH}=\mathrm{CHCH}_{2}\right)_{3}\left(\mathrm{CH}_{2}\right)_{6} \mathrm{COOH}$.

Spektra puncak kelima dengan $t_{R}=19,949$ memiliki kemiripan dengan spektra massa $(Z, Z, Z)$-metil linolenat atau metil 9Z,12Z,15Z-oktadekatrienoat dari WILLEY229.LIB dengan nomor entry 
14197 dan tingkat kemiripan $95 \%$ (Gambar

5.4). Kedua spektra memiliki kesamaan pada ion fragmen pada m/z: 39, 41, 55, 67, 79, 93, 108, 121, 135, 149, dan memiliki base peak pada m/z: 79. Sehingga disimpulkan bahwa kandungan asam $\alpha$ linolenat hasil hidrolisis minyak biji selasih sebesar 70,72\%.

Berdasarkan data-data tersebut disimpulkan bahwa asam lemak utama pada minyak biji selasih adalah asam 9Z,12Z,15Z-oktadekatrienoat atau asam $\alpha$ linolenat dengan geometri $Z, Z, Z$. Asamasam lemak hasil hidrolisis selanjutnya dipisahkan dengan inklusi urea untuk mendapatkan asam $\alpha$-linolenat dengan kemurnian yang lebih tinggi.

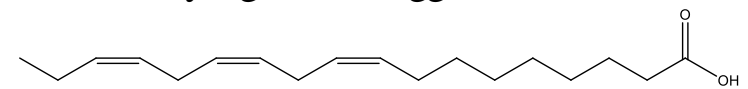

Gambar 4. Struktur asam 9Z,12Z,15Zoktadekatrienoat

\section{Hasil Isolasi Asam $\alpha$-Linolenat dengan Inklusi Urea}

Urea merupakan salah satu molekul induk yang sering digunakan dalam inklusi. Biasanya kristal urea berbentuk tetragonal, tetapi apabila ada molekul tamu, urea akan mengkristal dalam bentuk heksagonal yang mengandung molekul tamu di dalamnya. Kisi-kisi heksagonal dapat terbentuk hanya apabila terdapat molekul tamu dimana stabilitas strukturnya dipengaruhi gaya van der Waals antara molekul induk dan molekul tamu.

Kisi-kisi urea memiliki diameter $5 \AA$ yang terbentuk oleh ikatan-ikatan hidrogen. Bagian dalam bersifat kurang polar dibandingkan bagian luar, sehingga molekul organik nonpolar akan terpisah dan berada di dalam kisi-kisi kristal (Smith dan March, 2001). Selain itu, ukuran molekul juga berpengaruh pada pemisahan molekulmolekul organik dengan inklusi urea. Molekul yang terlalu besar karena tidak akan cocok dengan kisi-kisi kristal sehingga tidak dapat masuk ke dalam kisi-kisi kristal, namun apabila molekul organik tersebut terlalu kecil maka molekul tersebut akan keluar melalui lubang bawah.
Asam-asam lemak hasil hidrolisis minyak biji selasih merupakan campuran berbagai asam lemak, baik jenuh maupun tak jenuh. Menurut Anger, et al. (1996) minyak biji selasih memiliki kandungan asam lemak tak jenuh rata-rata $89 \%$, yaitu asam $\alpha$-linolenat $(43,8-64,8 \%)$, asam linoleat $(17,8-31,3 \%)$, dan asam oleat $(8,5-13,3 \%)$. Sedangkan kandungan beberapa asam lemak jenuhnya yaitu asam palmitat $(6,1-11,0 \%)$ dan asam stearat $(2,0-4,0 \%)$.

Ikatan rangkap bersifat lebih polar daripada ikatan tunggal. Asam lemak tak jenuh bersifat lebih polar daripada asam lemak jenuh. Semakin banyak ikatan rangkap dalam asam lemak, semakin besar pula sifat kepolarannya. Hal inilah yang mendasari pemisahan asam lemak menggunakan inklusi urea. Asam lemak jenuh yang bersifat kurang polar akan lebih mudah terjebak dalam kisi-kisi kristal urea daripada asam lemak tak jenuh. Demikian pula asam lemak tak jenuh yang memiliki satu ikatan rangkap (asam oleat) akan mudah terjebak dalam kisi-kisi kristal urea daripada asam linoleat (mengandung dua ikatan rangkap) dan asam linolenat yang mengandung tiga ikatan rangkap, sehingga asam linolenat dapat dipisahkan atau dimurnikan dengan inklusi urea.

Selain berdasarkan kepolaran, pemisahan asam lemak dengan inklusi urea juga dipengaruhi oleh ukuran atau konformasi asam lemak yang akan dipisahkan. Asam lemak jenuh akan lebih mudah masuk (terjebak) dalam kisi-kisi kristal urea dibanding asam lemak tak jenuh. Asam lemak jenuh hanya mengandung rantai karbon dengan ikatan tunggal yang dapat mengalami perputaran (rotasi) pada ikatan-ikatannya, sehingga bentuk molekul dan ukurannya lebih fleksibel. Sedangkan asam lemak tak jenuh memiliki bentuk molekul yang lebih kaku (rigid) pada ikatan rangkapnya. Ikatan rangkap tidak dapat mengalami perubahan konformasi seperti pada ikatan tunggal, sehingga akan lebih terhalang untuk masuk ke dalam kisi-kisi kristal urea. 
Pemisahan asam-asam lemak dengan inklusi urea juga dipengaruhi jumlah ikatan rangkap dan geometri dari asam-asam lemak tersebut. Asam lemak dengan satu ikatan rangkap (monoena), dua ikatan rangkap (diena), dan tiga ikatan rangkap (triena), serta asam lemak dengan geometri $E$ atau $Z$ akan mengalami interaksi yang berbeda dengan kristal urea, sehingga dapat mengalami pemisahan. Penelitian yang dilakukan oleh Grandgirard (1987) mengenai inklusi urea pada asam lemak minyak biji rami (linseed oil) dengan perbandingan urea:asam lemak 2:1 pada temperatur $4{ }^{0} \mathrm{C}$ menghasilkan pemisahan antara asam $\alpha$-linolenat dan asam non linolenat. Asam-asam lemak non linolenat terperangkap dalam kristal urea. Asam palmitat terperangkap sebanyak $99,1 \%$, asam palmitoleat 62,5 \%, asam heptadekanoat $100 \%$, asam heptadekaenoat $75 \%$, asam stearat $99,4 \%$, asam oleat 89,8 $\%$, asam linoleat (18:2 Z,E dan $E, Z) 83 \%$, dan $(18: 2 Z, Z) 34,9 \%$. Hanya sedikit asam $\alpha$-lonolenat $(18: 3 \quad Z, Z, Z)$ yang terperangkap, yakni sekitar 27,1 \% sedangkan sisanya tetap berada dalam filtrat.

Hasil pemisahan dengan inklusi urea dipengaruhi oleh temperatur dan perbandingan (rasio) urea dan asam lemak yang akan dipisahkan. Pada penelitian ini, dilakukan variasi temperatur dan rasio asam lemak: urea untuk mencari kondisi optimum inklusi yang selanjutnya digunakan pada saat proses purifikasi asam $\alpha$-linolenat campuran hasil hidrolisis minyak biji selasih.

\section{Optimasi Inklusi Urea dengan Variasi Temperatur}

Optimasi inklusi urea dengan variasi temperatur dilakukan pada temperatur \pm 5 ${ }^{0} \mathrm{C}, \pm 3{ }^{0} \mathrm{C}, \pm 1{ }^{0} \mathrm{C}, \pm(-1){ }^{0} \mathrm{C}, \pm(-3){ }^{0} \mathrm{C}$ dan $\pm(-\overline{5}){ }^{0} \mathrm{C}$ dengan perbandingan asam lemak urea 1:2. Asam lemak yang terendapkan bersama urea dan asam lemak yang tidak terendapkan dipisahkan dengan penyaringan. Asam lemak yang tidak terendapkan (filtrat) dipekatkan dengan aliran gas $\mathrm{N}_{2}$ kemudian diesterifikasi untuk selanjutnya diidentifikasi dengan kromatografi gas (GC) untuk mengetahui temperatur inklusi yang menghasilkan asam $\alpha$-linolenat dengan kandungan yang paling tinggi. Hasil variasi temperatur inklusi urea ditunjukkan pada Gambar 5.

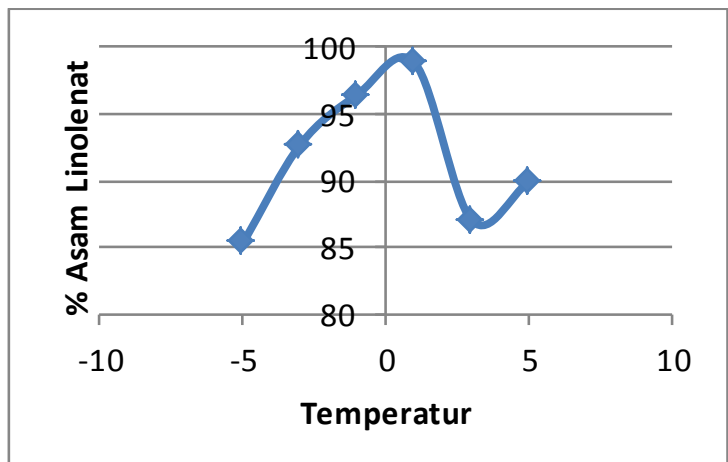

Gambar 5. Pengaruh Variasi Temperatur Inklusi Terhadap Kadar Asam Linolenat

Kadar asam linolenat pada temperatur $1{ }^{0} \mathrm{C}$ lebih besar daripada kadar asam linolenat pada temperatur $5{ }^{0} \mathrm{C}$ dan 3 ${ }^{0} \mathrm{C}$. Hal ini menunjukkan bahwa semakin banyak asam lemak jenuh atau yang hanya mengandung satu dan dua ikatan rangkap dua yang terjebak dalam kisi-kisi urea dan mengendap sehingga dapat dipisahkan dengan asam linolenat yang masih berada dalam filtrat. Namun, apabila temperatur diturunkan lagi menjadi $(-1){ }^{0} \mathrm{C},(-3){ }^{0} \mathrm{C}$ dan (-5) ${ }^{0} \mathrm{C}$ kadar asam linolenat semakin menurun karena sebagian asam linolenat juga mengalami pengendapan.

Dari Gambar 5 diketahui bahwa temperatur optimum inklusi urea adalah 0-2 ${ }^{0} \mathrm{C}$. Pada temperatur tersebut kadar asam linolenat hasil inklusi sebesar 98,81\% dengan rendemen sebesar 34,26\%. Temperatur inilah yang digunakan dalam optimasi inklusi urea dengan variasi rasio asam lemak:urea.

\section{Optimasi Inklusi Urea dengan Variasi Rasio Asam lemak: Urea}

Optimasi inklusi urea dengan variasi temperatur dilakukan pada temperatur optimum inklusi hasil penelitian sebelumnya, yaitu $0-2{ }^{0} \mathrm{C}$, dengan variasi 
rasio asam lemak urea $1: 1 ; 1: 1,5 ; 1: 2 ; 1: 2,5$; $1: 3 ; 1: 3,5 ; 1: 4$. Asam lemak yang tidak terendapkan (filtrat) dipekatkan dengan aliran gas $\mathrm{N}_{2}$ kemudian diesterifikasi untuk selanjutnya diidentifikasi dengan kromatografi gas (GC) untuk mengetahui rasio asam lemak:urea yang menghasilkan asam $\alpha$-linolenat dengan kandungan yang paling tinggi. Hasil variasi rasio asam lemak: urea ditunjukkan pada Gambar 6.

Kadar asam linolenat paling tinggi diperoleh pada rasio asam lemak:urea 1:1,5 yaitu sebesar 93,79 \%. Hal ini menunjukkan semakin banyak asam lemak jenuh atau monoena dan diena yang terjebak dalam kisi-kisi urea dan mengendap sehingga dapat dipisahkan dengan asam linolenat yang masih berada dalam filtrat. Pada rasio asam lemak:urea 1:1 kadar asam linolenat lebih kecil karena jumlah urea tidak mencukupi untuk membentuk kompleks klatrat dengan semua asam lemak non linolenat, sehingga masih ada asam lemak nonlinolenat yang tidak mengendap. Pada rasio asam lemak:urea 1:3,5 dan 1:4 kadar asam linolenat mengalami peningkatan, namun kadar asam linolenat semakin menurun dengan bertambahnya rasio asam lemak:urea karena sebagian asam linolenat juga mengalami pengendapan.

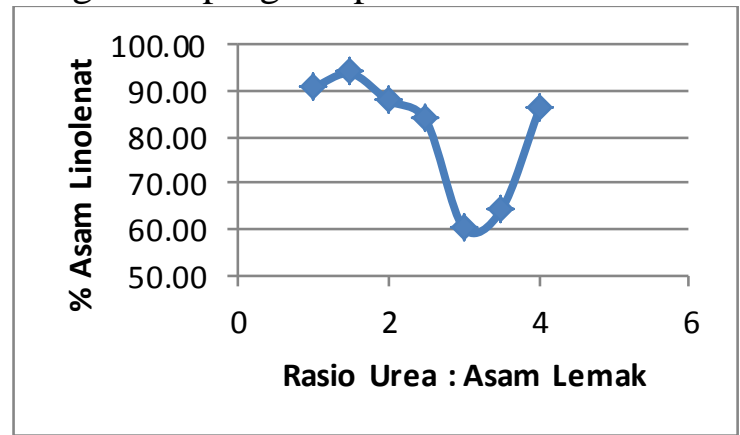

Gambar 6. Pengaruh rasio asam lemak:urea terhadap kadar asam linolenat

Dari Gambar 6 diketahui bahwa rasio asam lemak:urea optimum inklusi urea adalah 1:1,5. Pada rasio tersebut kadar asam linolenat hasil inklusi sebesar 93,79\% dengan rendemen dan recovery sebesar $23,51 \%$ dan $20,00 \%$. Temperatur dan rasio asam lemak:urea inilah yang digunakan dalam pemurnian (isolasi) $\alpha$-linolenat biji selasih.

\section{Isolasi Asam Linolenat pada Kondisi Optimum Inklusi}

Isolasi asam $\alpha$-linolenat biji selasih dilakukan pada kondisi optimum inklusi yang diperoleh dari percobaan sebelumnya, yaitu pada temperatur $0-2{ }^{0} \mathrm{C}$ dan rasio asam lemak:urea 1:1,5. Inklusi dilakukan tiga tahap, hasil dari inklusi pertama dïnklusi lagi dengan kondisi yang sama, kemudian hasilnya diinklusi lagi untuk ketiga kalinya. Kemurnian asam $\alpha$-linolenat yang diperoleh ditentukan dari hasil analisis dengan kromatografi gas-spektroskopi massa (KG-SM). Kromatogram KG hasil inklusi ditunjukkan Gambar 7.

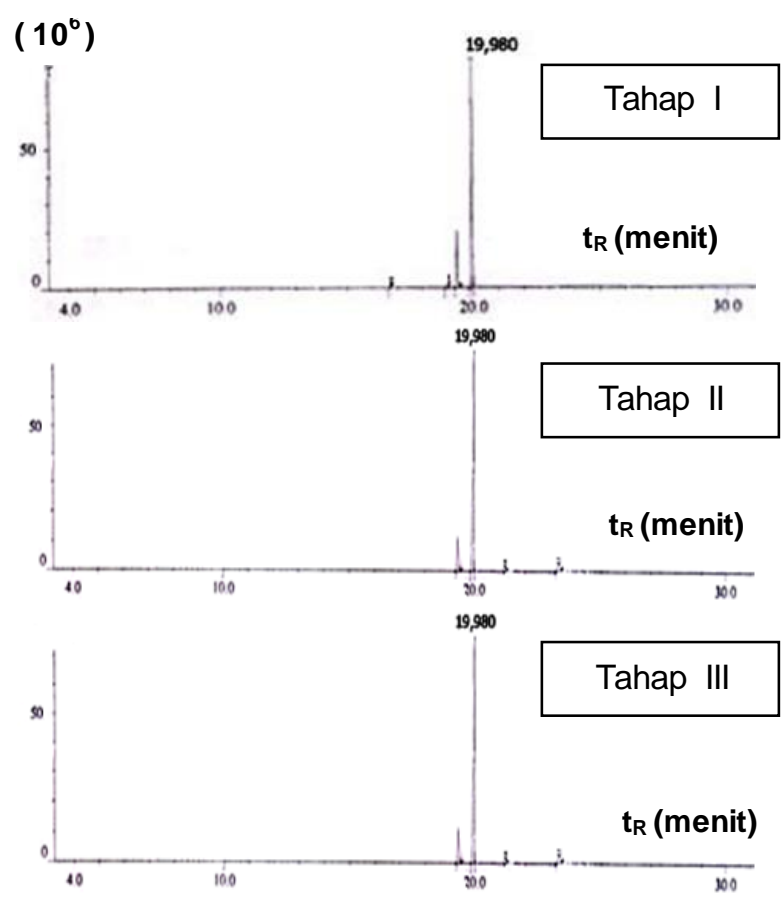

Gambar 7. Kromatogram KG Metil Ester Asam Lemak Hasil Inklusi Urea

Dari data KG diketahui bahwa komponen utama pada hasil inklusi I, II, dan III memiliki nilai waktu retensi yang sama yaitu 19,980 menit. Komponen tersebut meningkat dari inklusi I, inklusi II, dan inklusi III, yaitu sebesar 79,39\%, 85,00 $\%$ dan 88,51 \% (Tabel 2). Hal ini menunjukkan tingkat kemurnian yang meningkat pula. Dengan kata lain, semakin bagus pemisahan asam linolenat dengan asam lemak nonlinolenat. 
Tabel.2. Persentase Komponen Utama Hasil Inklusi Urea

\begin{tabular}{|c|l|c|c|}
\hline $\begin{array}{c}\mathrm{N} \\
\mathrm{o}\end{array}$ & Inklusi & $\begin{array}{c}\text { Waktu } \\
\text { Retensi } \\
\text { (menit) }\end{array}$ & \% as am linolenat \\
\hline 1 & Tahap I & 19,980 & 79,39 \\
\hline 2 & Tahap II & 19,980 & 85,00 \\
\hline 3 & Tahap III & 19,980 & 88,51 \\
\hline
\end{tabular}

Komponen utama hasil inklusi diperkirakan merupakan asam $\alpha$-linolenat. Hal ini didukung hasil analisis Spektra massa pada Gambar 8 .

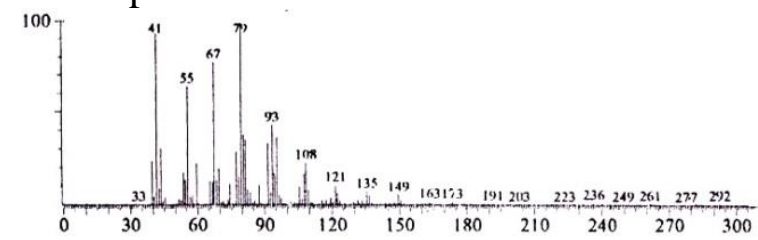

Gambar 8. Spektra Massa Metil Ester Asam

Lemak Hasil Inklusi Urea $\left(t_{R}=19,980\right)$

Spektra massa metil ester hasil inklusi menghasilkan puncak ion fragmen pada m/z: 39, 41, 55, 67, 79, 93, 108, 121, $135,149,163,173,191,203,217,236$, 249, 261, 277 dan 292. Spektra tersebut memiliki kemiripan dengan spektra massa $(Z, Z, Z)$-metil linolenat atau metil 9Z,12Z,15Z-oktadekatrienoat (Gambar 3).

Kedua spektra memiliki kesamaan pada ion fragmen pada $\mathrm{m} / \mathrm{z}: 39,41,55,67$, 79, 93, 108, 121, 135, 149 dan memiliki base peak pada m/z: 79. Berdasarkan datadata tersebut disimpulkan bahwa asam lemak utama hasil inklusi adalah asam 9Z,12Z,15Z-oktadekatrienoat atau asam $\alpha$ linolenat dengan geometri $Z, Z, Z$.

Hasil spektra massa didukung hasil analisis dengan spektroskopi UV. Gambar 10 menunjukkan panjang gelombang maksimum pada panjang gelombang 210 dan $230 \mathrm{~nm}$. Serapan pada panjang gelombang maksimum $230 \quad \mathrm{~nm}$ mengindikasikan adanya asam lemak yang mengandung dua ikatan rangkap terkonjugasi. Hal ini sesuai dengan perhitungan panjang gelombang maksimum kromofor induk diena terkojugasi dengan aturan Woodward-Fischer. Sedangkan serapan pada panjang gelombang $210 \mathrm{~nm}$ dimungkinkan asam lemak dengan ikatan rangkap yang tidak terkonjugasi.

Berdasarkan nilai absorbansinya, puncak dengan panjang gelombang maksimum $210 \mathrm{~nm}$ memiliki absorbansi yang lebih besar, yaitu 3,356. Hal ini menunjukkan banyaknya asam lemak dengan ikatan rangkap yang tidak terkonjugasi. Apabila dikaitkan dengan kandungan asam lemak hasil hidrolisis dari biji selasih, asam lemak yang paling banyak adalah asam linolenat, dapat disimpulkan bahwa asam lemak tersebut adalah asam $\alpha$ linolenat (asam 9,12,15-oktadekatrienoat).

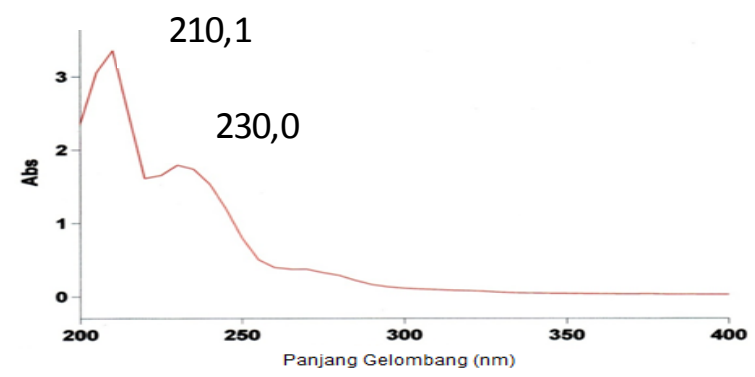

Gambar 9. Spektra UV Asam Lemak Hasil Inklusi Urea

Sedangkan senyawa campurannya adalah asam lemak yang memiliki dua ikatan rangkap terkonjugasi (memiliki absorbansi UV pada $230 \mathrm{~nm}$ ) dan sejumlah kecil asam lemak jenuh. Adapun rendemen hasil inklusi tahap I, tahap II, dan tahap III disajikan pada Tabel. 3 .

Tabel. 3. Hasil Inklusi Urea

\begin{tabular}{|c|c|c|c|c|}
\hline $\begin{array}{l}\mathrm{N} \\
\mathrm{O}\end{array}$ & Inklusi & $\begin{array}{l}\text { Berat } \\
\text { Sampel }(g)\end{array}$ & $\begin{array}{l}\text { Berat } \\
\text { Hasil (g) }\end{array}$ & $\begin{array}{l}\text { Rendemen } \\
(\%)\end{array}$ \\
\hline \multirow[t]{4}{*}{1} & \multirow[t]{4}{*}{ Tahap I } & 75 & 16,30 & 22,17 \\
\hline & & 75 & 13,30 & 17,73 \\
\hline & & 75 & 13,58 & 18,11 \\
\hline & & & Rerata & 19,95 \\
\hline \multirow[t]{4}{*}{2} & \multirow[t]{4}{*}{ Tahap II } & 15 & 6,97 & 46,47 \\
\hline & & 15 & 6,81 & 45,40 \\
\hline & & 15 & 6,75 & 45,00 \\
\hline & & & Rerata & 45,62 \\
\hline \multirow[t]{4}{*}{3} & \multirow[t]{4}{*}{ Tahap III } & 6,75 & 2,35 & 34,81 \\
\hline & & 6,75 & 2,22 & 32,89 \\
\hline & & 6,75 & 2,09 & 30,96 \\
\hline & & & Rerata & 32,89 \\
\hline
\end{tabular}

Ket : temperatur $0-2{ }^{\circ} \mathrm{C}$ dan rasio asam lemak urea $1: 1,5$ 
Dari Tabel 3. diketahui bahwa rendemen rata-rata inklusi pertama adalah sebesar $19,95 \%$, inklusi kedua 45,62 \%, dan inklusi ketiga 32,89 \%. Pada inklusi pertama rendemen agak rendah karena banyak asam lemak nonlinolenat yang masih harus dipisahkan, sedangkan pada inklusi kedua tinggal sedikit asam lemak nonlinolenat yang terpisahkan sehingga rendemennya cukup besar. Pada inklusi ketiga dimungkinkan sebagian asam linolenat ikut terendapkan bersama kristal urea sehingga rendemennya kembali menurun.

\section{KESIMPULAN}

Asam-9Z,12Z,15Z-oktadekatrienoat dari biji selasih (ocimum basilicum) dapat diisolasi dengan beberapa tahap. Tahap pertama, isolasi minyak biji selasih dilakukan dengan ekstraksi Soxhlet menggunakan pelarut n-heksana. Minyak biji selasih yang diperoleh dari hasil isolasi mempunyai indeks bias rata-rata 1,4661 dan berat jenis 0,8553. Tahap kedua, hidrolisis minyak biji selasih dengan merefluks dengan $\mathrm{KOH} 12 \%$ pada temperatur $60{ }^{0} \mathrm{C}$ selama 90 menit. Hidrolisis minyak biji selasih menghasilkan campuran asam-asam lemak dengan rendemen sebanyak $77,90 \%$, recovery $81,81 \%$, indeks bias 1,4593 , dan berat jenis 0,8853. Asam-asam lemak minyak biji selasih terdiri dari asam palmitat $(4,98 \%)$, asam stearat $(2,02 \%)$, asam oleat $(6,46 \%)$, asam linoleat $(15,83 \%)$, dan asam $\alpha$ linolenat $(70,72 \%)$. Asam $\alpha$-linolenat dapat diisolasi dengan metode inklusi urea pada tetemperatur optimum inklusi $0-2{ }^{0} \mathrm{C}$ dan rasio asam lemak : urea 1,5:1. Hasil pemisahan dengan inklusi urea tiga tahap menghasilkan asam-9Z,12Z,15Z oktadeka trienoat dengan kemurnian $88,51 \%$.

\section{DAFTAR PUSTAKA}

Angers, P., M.R. Morales, and J.E. Simon. 1996. Basil seed oils, p. 598-601. In: J. Janick (ed.). Progress in new crops. ASHS Press. Arlington. VA.

Dewi, S.P. 2009. Isolasi Asam $\alpha$-linolenat dalam Biji Selasih (Ocimum basilicum L.) Menggunakan Metode Perbedaan Titik Beku, Skripsi FMIPA. Universitas Brawijaya. Malang

Harrison, K. 2006. Linolenic Acid (LA), http://www.3dchem.com/magesofm olecules/linolenicacid.jpg\&imgrefurl. diakses 18 Oktober 2008

Mendes, A., T.S. da Silva, and A. Reis. 2006. DHA Concentration and Purification from the Marine Heterotropic Microalga Crypthecodinium cohnii CCMP 316 by Winterization and Urea Complexation, Food Tchnol. Biotechnol. 45 (1): 38-44

Choi,Y., Park,Y., Pariza,M.W., and Ntambi,J.M. 2001. Regulation of Stearoyl-CoA Desaturase Activity by the trans 10, cis 12 Isomer of Conjugated Linolenic Acid in HepG2 Cells, Biochem. Biophys. Res. Commun. 284. 289-293

Muhsin B. 2007. Kenali Omega 3 dan Omega 6 Lebih Banyak Lagi, http://www.nutrisibalitacerdas.com/ $\underline{\text { module.php?act }=\text { article } \& \text { mode }=\text { read }}$ \&articleID=26\&categoryID=7, diakses 19 Mei 2008

Ohlan, R., B. Narashimhan, S.Ohlan, R. Narang and V. Judge. 2008. Synthesis and Antimocrobial Evaluation of Urea Inclusio Complexes, Org. Commun. 1(2) : 24-32 